\title{
RESPONSE OF DATE PALM (PHOENIX DACTYLIFERA) TO COMBINATIONS OF ORGANIC AND TRANSPLANTS INORGANIC FERTILIZERS UNDER DIFFERENT IRRIGATION SYSTEMS IN THE NEW VALLEY
}

\author{
Soliman E. M. ${ }^{(1)}$; Medany M. A. ${ }^{(2)}$ and Soliman M. F \\ 1) Institute of Environmental Studies and Researches, Ain Shams University \\ 2) Agricultural Research Center
}

\begin{abstract}
This trial was conducted under commercial field conditions in Dakhla Oasis, New Valley Governorate- Egypt, in order to investigate the influence of two irrigation systems (flood and drip irrigation), combinations of organic and inorganic fertilizers and different date palm (Phoenix dactylifera) cultivars (i.e. Barhi, Sagae. Khadry and Majdool) in sandy soil during the study season (2013 - 2014). Four different combinations of organic and mineral fertilizers were evaluated as compared to the control (i.e. $100 \%$ mineral). The treatments include (1)100\% mineral; (2) $100 \%$ cattle manure; (3) $100 \%$ chicken manure; (4) $50 \%$ mineral plus $50 \%$ cattle and (5) $50 \%$ mineral plus $50 \%$ chicken manure. . All treatments were arranged in a splitsplit plot design with three replicates; irrigation systems were arranged in the main plot while the combination of organic and inorganic fertilizers were arranged in sub plot, and date palm cultivars were arrange in sub-sub plot. Vegetative growth parameters (Plant length and number of leaves) were measured as well as physical and chemical characteristics of soil before and after application were analyzed.

The results showed that application of different organic manures to the sandy soil improved its physical properties including soil field capacity, wilting point conductivity as well as available water compared to the soil without organic manures (control). The chemical analysis of soil indicated that, flood irrigation led to decrease soil $\mathrm{pH}$; the $100 \%$ of manure fertilizer decreased soil $\mathrm{pH}$ more than other fertilizers combinations. The cation exchange capacity (CEC) showed similar trend as that of $\mathrm{pH}$. In contrast, the
\end{abstract}


soil EC had different trend; the $100 \%$ mineral fertilizers gave the lowest EC values followed by $50 \%$ mineral plus $50 \%$ organic fertilizers; the highest soil EC was obtained by $100 \%$ cattle or chicken manure. The pH, CEC and EC of soil were higher under drip irrigation as compared to flood irrigation system.

Date palm plant growth was influenced by increasing organic manure under irrigation system. Plant length and number of leaves per plant were increased by $50 \%$ mineral and 50\% cattle under drip irrigation as compared to other treatments. The highest plant growth parameter was obtained by $50 \%$ mineral and 50\% cattle combined with drip irrigation system for Majdool cultivar during the experimental season.

Key words: Organic manure, Cattle manure, Chicken manure, Sandy soil, Irrigation, Date palm.

\section{INTRODUCTION}

Date palm (Phoenix dactylifera) is an important tree crop of the semi and arid regions where it grows in unplanted and cultivated groves with little rains and high evapotranspiration. The date palm (Phoenix dactylifera L.) is the most important tree grown in arid and semi-arid regions. The date palm is one of the main causes for sustainability of human life in many of the arid parts of the old world (Sawaya, 2000). As a general rule in date palm fertilization, 2 to $3 \mathrm{~kg} \mathrm{~N}$ per date palm tree per year for fully grown palm is recommended (Arar, 1975). This amount could be applied in two to three applications in sandy soils. In the Middle-east and North Africa, the better date palm gardens use organic manures which are often buried in deep circular trenches around the palms. These manures are usually dung of animals and are used at rates of 1 - 37 Ton/ ha (Arar, 1975). In long term studies, organic manures have been shown to largely improve soil physical conditions such as moisture retention capacity and aggregate soil stability, crop water use efficiency (Hati et al., 2006), improve soil fertility, crop performance and yield (Kaur et al., 2005; 106 
Sarkar et al., 2003; Bokhtiar and Sakurai, 2005; Hossain and Ishimine, 2007; Tirol-Padre et al., 2007). In Egypt cultivation of date palm goes back to thousands of years. Nowadays ,date palms are spread all over Egypt, wherever water is available (Riad, 1996) and date industry supports over one million people (Bazza, 2008). Recently, there are about 14 million trees, occupying 30,934 ha, which represent $6.32 \%$ of the fruit cultivated area in Egypt. Date productions of Egypt represent about $20 \%$ of the total world production (FAOSTAT 2009). While organic manure may be beneficial to crops on the long term, their efficiency in enhancing crop growth and yield in the short term have, in most cases, been enhanced with combination of inorganic fertilizers. Kaur et al., (2005) showed that palm tree were enhanced when inorganic fertilizer was combined with organic manures.

The date palm like any other fruits need to adoption of a proper fertilization program (including adequate rates, appropriate sources, and efficient application methods and timing) is an important strategy for obtaining better fruit yield and quality. On the other hand, organic wastes are critically needed to be applied as soil amendments for improving soil properties at the same time as slow release fertilizers. This study was conducted to investigate the impact of soil conditioner on soil properties as well as irrigation requirements of date palm. The main aim of this study was to investigate the response of palm trees to different irrigation systems as well as to determine the efficient combination of organic and inorganic fertilizers. 
J. Environ. Sci.

Institute of Environmental Studies and Research - Ain Shams University

\section{MATERIALS AND METHODS}

Study location: The present study was conducted to investigate the protocol for date palm production in Dakhla Oasis, New Valley Governorate, Egypt $\left(25^{\circ} 26^{\prime} 18^{\prime \prime} \mathrm{N}, 30^{\circ} 33^{\prime} 30^{\prime \prime} \mathrm{E}\right)$ during the study seasons of $2013 / 2014$.

Plant materials: One year old seedlings (Fasilah) were planted in sandy soil at October 5th 2013. The space between each two rows was eight meters, and the space between the two plants inside the same row was eight meters. Four new imported date palm cultivars were used in this investigation i.e. Barhi, Segae, Khodry and Majdool, each cultivar was presented by 60 seedlings (Fasilah). Total of 240 tissue culture date palm seedlings (Fasilah) were acclimated for one year under net-house conditions until the seedlings attained $2-3$ leaves.

Study treatments: The study includes the effect of three factors combinations of organic and inorganic fertilizers, irrigation system and date palm cultivars.

Organic manure: Four different combinations of organic and mineral fertilizers were tested compared to the control (100\% mineral): the applications were (1)100\% mineral fertilization (Mineral fertilization was added to the mixture according to, the recommendation of the Ministry of Agriculture and Land Reclamation); (2) 100\% cattle manure; (3) $100 \%$ chicken manure; (4) $50 \%$ mineral plus $50 \%$ cattle and (5) $50 \%$ mineral plus $50 \%$ chicken manure. Each treatment contained 24 seedlings (six seedlings of each cultivar). 
Irrigation system: two irrigation system (flood irrigation and drip irrigation) water requirement calculated by Penman-Monteith equation (Allen et al., 1998). The drip irrigation system was applied by one polyethylene hose (lateral) for each row; bubblers were installed for each date palm tree (120 liters per hour). Flood irrigation was applied by basin system. Each basin was contained four date palm trees. Each irrigation treatment contained 120 date palm seedlings (30 seedlings of each tested cultivars).

Date palm cultivars: Four new imported cultivars (i.e. Barhi, Segae. Khodry and Majdool) were cultivated in sandy soil.

Experimental design: All treatments were arranged in split-split plot design with three replicates; irrigation systems were arranged in the main plot and combination of organic and mineral fertilizers were arranged in sub main plot. However, the date palm cultivars were arranged in the sub-sub plot.

Measurements: Vegetative growth parameters (Plant length and number of leaves) were measured at the age of 12 months, physical and chemical characteristics of soils were analyzed before and after application of fertilizer treatments.

Soil analysis: Soil samples analyses of $30 \mathrm{~cm}$ depth for the experimental site were performed, before planting (Table 1 \& 2). Physical and chemical properties of soil were described by Piper (1950), Jackson (1967) and Black (1969). 
Table (1): Physical and chemical characteristics of soils.

\begin{tabular}{|c|c|c|c|c|c|c|c|c|c|c|c|c|c|}
\hline 芯 & $\frac{\vec{E}}{U}$ & 击 & ta & ப & $\tilde{0}$ & ชి & $\ddot{z}$ & 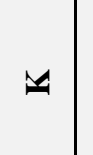 & שే & $\sum^{\infty}$ & U. & 흘 & 竞 \\
\hline \multicolumn{4}{|c|}{$\%$} & \multicolumn{7}{|c|}{ Milliequivlent / Liter } & $\begin{array}{l}\text { Meq/ } \\
\text { 100g }\end{array}$ & \multicolumn{2}{|c|}{$\%$} \\
\hline 94.5 & 2 & 3.5 & 7.4 & 1.4 & 2.1 & 0.0 & 1.5 & 0.26 & 1 & 1 & 4.1 & 10.5 & 26.0 \\
\hline
\end{tabular}

Table (2): Organic manure analysis

\begin{tabular}{|c|c|c|c|c|}
\hline & $\mathbf{O . M \%}$ & $\mathbf{C \%}$ & $\mathbf{K \%}$ & $\mathbf{N \%}$ \\
\hline \hline Cattel Manure & 55.72 & 16.86 & 1.05 & 1.57 \\
\hline Chicken Manure & 47.67 & 28.86 & 1.26 & 2.09 \\
\hline
\end{tabular}

\section{RESULTS AND DISCUSSION}

\section{Effect of different organic manures and irrigation system on soil chemical properties.}

1.1 Soil Ph: The data in Table (3) represent the $\mathrm{pH}$ of the investigated treatments after application of fertilizer and irrigation treatments. The results indicated that flood irrigation system was effective in decreasing soil $\mathrm{pH}$ compared to drip irrigation system. Soil $\mathrm{pH}$ decreased in treated sandy soil with the application of organic fertilizers. However, the decreasing in soil $\mathrm{pH}$ among different treatments was relatively small. Also, the results showed that $100 \%$ chicken manure was more effective in decreasing soil $\mathrm{pH}$ as compared to the other treatments.

Regarding the interaction effect between the two irrigation systems and fertilization treatments, there was significant effect among treatments during the experimental seasons. The highest $\mathrm{pH}$ was obtained by $50 \%$ mineral plus 
$50 \%$ chicken combined with drip irrigation followed by $100 \%$ mineral fertilization combined with drip irrigation system. In addition, flood irrigation system combined with $100 \%$ chicken manure recorded the lowest $\mathrm{pH}$ value.

The changes were remarkable and acceptable due to the low buffering capacity of the sandy soil and could be attributed to production of organic and inorganic acids from organic manure through decomposition processes by soil microbes (Adel, 1980).

\subsection{Cation Exchange Capacity (CEC): Cation exchange capacity is} important to soil nutrient availability in relation to the nutrient saturation of soil colloids and the type of soil colloids. Soil CEC almost had the same trend of the observed data of soil $\mathrm{pH}$. The $\mathrm{pH}$ can indicate the amount of acidity present in soils with identical cation-exchange properties (Westerman, 1990).

Data presented in Table (3) showed that the CEC values significantly increased in all treatments particularly that contained 50\% mineral plus 50\% cattle followed by $50 \%$ mineral plus $50 \%$ chicken. The lowest CEC values were obtained by $100 \%$ mineral fertilizers. This may be due to that the improving conditions and acceleration of decomposition process lead to produce more organic acids.

Regarding the interaction effect between different irrigation systems and organic fertilization, there was significant effect among treatments during the experimental seasons. The highest CEC values were obtained by $50 \%$ mineral plus $50 \%$ cattle manure combined with drip irrigation followed by $50 \%$ mineral plus $50 \%$ chicken manure combined with drip irrigation. In addition, flood irrigation system combined with $100 \%$ mineral fertilizers recorded the lowest CEC value. 
The CEC is related to accumulation of humic substance (Dayegamlye, et. al. 1997). In addition, the value of CEC increases also by increasing the $\mathrm{pH}$ due to the important role of humus material in increasing the availability of nutrients in soils, (Knonova, 1966).

1.3 Electrical conductivity (EC): Data presented in Table (3) indicated that flood irrigation was more effective on decreasing the EC values than drip irrigation system. The highest EC values are recorded with application of $100 \%$ chicken manure followed by $100 \%$ cattle manure; the lowest EC was obtained by $100 \%$ mineral fertilizer.

Regarding the interaction effect between different irrigation system and fertilization treatments, there was significant effect among treatments during the experimental seasons. The highest EC values were obtained by $100 \%$ chicken manure combined with drip irrigation followed by $100 \%$ cattle manure combined with drip irrigation. In addition, flood irrigation system combined with $100 \%$ mineral fertilizer recorded the lowest EC value.

Regarding the electric conductivity of sandy soil, it increased by more than 5 folds due to treating soil with organic manure. This may be due to the high soluble salts content in the organic manure. This finding coincided with those of (Adel, 1980) who mentioned that the rate of organic manure amendment increased, EC of soil increased too. Abdel El- Naim et. al (1975) showed that addition of organic wastes such as farmyard manure to soil led to increase the total soluble salts after six months of the experimental duration then decreased after ten months. Other possibility may be due to the relatively high ammonium content in the manures (Lila, 2001). 


\section{Effect of organic matter applications on field capacity, wilting point and available water after organic manure addition.}

Date in Table (4) show the field capacity and wilting percentage as well as available water in soil after the application of different organic and mineral fertilizers. The highest field capacity was obtained by $100 \%$ cattle manure application followed by $100 \%$ chicken manure; while the lowest field capacity was obtained by $100 \%$ mineral fertilizer treatment. The wilting point had almost the same trend, $100 \%$ of organic fertilizer led to increase wilting point. Using $100 \%$ chicken manure gave the highest wilting point followed by $100 \%$ cattle manure. The lowest wilting point was obtained by $100 \%$ mineral fertilizer. Finally, available water showed similar trend as field capacity with $100 \%$ cattle manure; while the $100 \%$ mineral fertilizer gave the lowest available water percentage.

\section{Effect of different organic manure and irrigation system on the} vegetative growth of date palm cultivars.

Irrigation system had positive effect on the number of leaves per plant and plant length (Tables $5 \& 6$ ). The highest mean values were obtained with the drip, and the lowest values were recorded for the flood irrigation system. The superiority of drip over flood irrigation may be attributed to the fact that bubblers can provide the palm with adequate water requirement and keep proper moisture in the plant root pattern. These results are in conformity with those obtained by Amiri et al. (2007) and Al- Subaiee et al. (2013).

Using of $50 \%$ cattle manure plus $50 \%$ mineral fertilizer gave the highest vegetative growth followed by $50 \%$ chicken manure plus $50 \%$ mineral fertilizer. 
Majdool cultivar gave the highest vegetative growth followed by Segae cultivar; while Barhi cultivar gave the lowest vegetative growth.

The vegetative growth parameters were significantly affected by the interaction between the irrigation system and different combination of fertilizers (Table 5\& 6). The highest values were obtained by $50 \%$ mineral plus $50 \%$ cattle combined with drip irrigation system followed by $50 \%$ mineral plus $50 \%$ chicken combined with drip irrigation system. This may be due to fact that water applied of 50\% mineral plus 50\% cattle under drip irrigation adequately meets the palm water and fertilizers requirements, while the other amounts did not. This result is in agreement with the findings of Hussein and Hussein (1983) and Wahba et al. (1990).

Regarding the interaction between irrigation system and date palm cultivars, data showed that the highest vegetative growth was obtained by the plants under the drip irrigation combined with Majdool treatment followed by drip irrigation combined with Segae treatment; while the lowest vegetate growth was gained by the flood irrigation combined with Barhi cultivar.

Regarding the interaction between organic fertilizer and cultivars, data showed that the highest vegetative growth was recorded with $50 \%$ mineral plus $50 \%$ cattle combined with Majdool treatment followed by the plants fertilized by $50 \%$ mineral plus $50 \%$ cattle combined with Segae cultivar. The lowest vegetative growth obtained by $100 \%$ chicken manure combined with Barhi. The differences among all treatments were significant. 
According to the interaction effect between the different irrigation method, organic fertilizer and palm cultivar, data showed that, there were significant differences resulted due to the interaction between the treatments. The highest plant length and number of leaves was observed under drip irrigation combined with $50 \%$ mineral plus $50 \%$ cattle treatment and Majdool cultivar, followed by drip irrigation combined with 50\% mineral plus 50\% cattle and Segae cultivar. While, the lowest plant length and number of leaves was recorded by flood irrigation combined with $100 \%$ chicken manure and Barhi.

\section{CONCLUSION}

It could be concluded that application of organic fertilizer with drip irrigation, is optimal for good date palm growth and fasilah quality (length and number of leaves). Also, application of organic fertilizer at 50\% mineral plus $50 \%$ cattle proved to be superior in terms of characteristics under study with drip irrigation. 
J. Environ. Sci.

Institute of Environmental Studies and Research - Ain Shams University

Table (3): Effect of interaction between organic manure and irrigation level on $\mathrm{pH}, \mathrm{CEC}$ and electrical conductivity of sandy soil.

\begin{tabular}{|c|c|c|c|c|c|c|c|c|c|}
\hline \multirow[t]{2}{*}{ Treatment } & $\begin{array}{l}\text { Flood } \\
\text { | Irrigation }\end{array}$ & $\begin{array}{c}\text { Drip } \\
\text { Irrigation }\end{array}$ & \multirow[t]{2}{*}{$\operatorname{Mean}(B)$} & \multicolumn{2}{|c|}{ SI Flood Jip } & \multirow[t]{2}{*}{$\operatorname{Mean}(\mathrm{B})$} & \multicolumn{2}{|c|}{$\begin{array}{l}\text { Surfact } \text { Flood } \\
\text { Irrigation | Irrigation }\end{array}$} & \multirow[t]{2}{*}{ Mean (B) } \\
\hline & \multicolumn{2}{|r|}{$\mathrm{pH}$} & & \multicolumn{2}{|r|}{ CEC } & & \multicolumn{2}{|r|}{$\mathrm{EC}$} & \\
\hline $\begin{array}{l}100 \% \text { mineral fertilization } \\
\text { (control) }\end{array}$ & 7.5 & 7.57 & 7.54 & 7.87 & 8.32 & 8.10 & 2.02 & 2.21 & 2.12 \\
\hline $50 \%$ mineral $+50 \%$ cattle & 7.44 & 7.54 & 7.49 & 9.17 & 9.29 & 9.23 & 2.25 & 2.33 & 2.29 \\
\hline $50 \%$ mineral $+50 \%$ chicken & 7.48 & 7.62 & 7.55 & 9.12 & 9.21 & 9.17 & 2.31 & 2.4 & 2.36 \\
\hline $100 \%$ cattle manure & 6.68 & 7.4 & 7.04 & 8.86 & 9.11 & 8.99 & 2.35 & 2.5 & 2.43 \\
\hline $100 \%$ chicken manure & 6.31 & 6.92 & 6.62 & 8.82 & 8.52 & 8.67 & 2.39 & 2.51 & 2.45 \\
\hline $\operatorname{Mean}(\mathrm{A})$ & 7.08 & 7.41 & & 8.77 & 8.89 & & 2.26 & 2.39 & \\
\hline LSD (A) Irrigation & \multicolumn{3}{|c|}{0.124} & \multicolumn{3}{|c|}{0.114} & \multicolumn{3}{|c|}{0.108} \\
\hline LSD (B) Fertilizer & \multicolumn{3}{|c|}{0.051} & \multicolumn{3}{|c|}{0.748} & \multicolumn{3}{|c|}{0.025} \\
\hline $\operatorname{LSD}(\mathrm{A} * \mathrm{~B})$ Interaction & \multicolumn{3}{|c|}{0.031} & \multicolumn{3}{|c|}{0.045} & \multicolumn{3}{|c|}{0.024} \\
\hline
\end{tabular}

Table (4):Effect of organic matter applications on field capacity, wilting point and available water after organic manure addition (\%).

\begin{tabular}{|c|c|c|c|}
\hline Treatment & $\begin{array}{c}\text { Field } \\
\text { capacity }\end{array}$ & $\begin{array}{c}\text { Wilting } \\
\text { point }\end{array}$ & $\begin{array}{c}\text { Available } \\
\text { water }\end{array}$ \\
\hline \hline 100\% mineral fertilization (control) & 10.82 & 3.84 & 6.98 \\
\hline 50\% mineral + 50\% cattle & 12.65 & 4.62 & 8.03 \\
\hline 50\% mineral + 50\% chicken & 11.54 & 4.22 & 7.32 \\
\hline 100\% cattle manure & 13.36 & 5.22 & 8.13 \\
\hline 100\% chicken manure & 13.16 & 5.62 & 7.54 \\
\hline
\end{tabular}


Table (5): Effect of interaction between organic manure and irrigation method on plant height (cm/plant) (12 months)

\begin{tabular}{|c|c|c|c|c|c|c|}
\hline irrigation.(A) & Fertilizer (B) & Barhi & Segae & Khodry & Majdool & Mean(B) \\
\hline \multirow{5}{*}{ 言 } & $\begin{array}{l}100 \% \text { mineral fertilization } \\
\text { (control) }\end{array}$ & 78.00 & 102.67 & 97.33 & 113.00 & 97.75 \\
\hline & $50 \%$ mineral $+50 \%$ cattle & 93.67 & 123.00 & 116.67 & 135.67 & 117.25 \\
\hline & $50 \%$ mineral $+50 \%$ chicken & 82.33 & 108.67 & 103.33 & 120.00 & 103.58 \\
\hline & $100 \%$ cattle manure & 70.67 & 82.13 & 86.27 & 94.67 & 83.44 \\
\hline & $100 \%$ chicken manure & 78.00 & 86.67 & 94.67 & 104.33 & 90.92 \\
\hline Mean & & 80.53 & 100.63 & 99.65 & 113.53 & 98.59 \\
\hline \multirow{5}{*}{$\frac{\bar{E}}{\Gamma}$} & $\begin{array}{l}100 \% \text { mineral fertilization } \\
\text { (control) }\end{array}$ & 66.33 & 86.00 & 86.00 & 97.33 & 83.92 \\
\hline & $50 \%$ mineral $+50 \%$ cattle & 79.67 & 103.33 & 103.00 & 117.00 & 100.75 \\
\hline & $50 \%$ mineral $+50 \%$ chicken & 70.67 & 91.33 & 91.00 & 103.00 & 89.00 \\
\hline & $100 \%$ cattle manure & 67.00 & 75.67 & 75.33 & 84.00 & 75.50 \\
\hline & $100 \%$ chicken manure & 63.00 & 81.67 & 82.00 & 92.67 & 79.84 \\
\hline Mean & & 69.33 & 87.60 & 87.47 & 98.80 & 85.80 \\
\hline \multirow{5}{*}{ 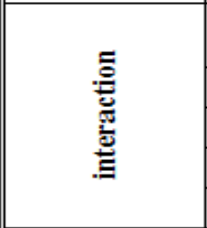 } & $\begin{array}{l}100 \% \text { mineral fertilization } \\
\text { (control) }\end{array}$ & 72.17 & 94.34 & 91.67 & 105.17 & 90.83 \\
\hline & $50 \%$ mineral $+50 \%$ cattle & 86.67 & 113.17 & 109.84 & 126.34 & 109.00 \\
\hline & $50 \%$ mineral $+50 \%$ chicken & 76.50 & 100.00 & 97.17 & 111.50 & 96.29 \\
\hline & $100 \%$ cattle manure & 68.84 & 78.90 & 80.80 & 89.34 & 79.47 \\
\hline & $100 \%$ chicken manure & 70.50 & $\mathbf{8 4 . 1 7}$ & 88.34 & 98.50 & 85.38 \\
\hline Mean (C) & & 74.93 & 94.11 & 93.56 & 106.17 & \\
\hline \multicolumn{5}{|c|}{ LSD Irrigation Type } & \multicolumn{2}{|l|}{6.39} \\
\hline \multicolumn{5}{|c|}{ LSD Different Fertilization } & \multicolumn{2}{|l|}{3.69} \\
\hline \multicolumn{5}{|c|}{ LSD Different Cultivars } & \multicolumn{2}{|l|}{5.21} \\
\hline \multicolumn{5}{|c|}{ LSD Irrigation Type * Different Fertilization } & \multicolumn{2}{|l|}{2.32} \\
\hline \multicolumn{5}{|c|}{ LSD Irrigation Type Different Cultivars } & \multicolumn{2}{|l|}{3.16} \\
\hline \multicolumn{5}{|c|}{ LSD Different Fertilization * Different Cultivars } & \multicolumn{2}{|l|}{1.51} \\
\hline
\end{tabular}


J. Environ. Sci.

Institute of Environmental Studies and Research - Ain Shams University

Table (6): Effect of interaction between organic manure and irrigation method on the number of leaves/plant (12 months)

\begin{tabular}{|c|c|c|c|c|c|c|}
\hline irrigation.(A) & Fertilizer (B) & Barhi & Segae & Khodry & Majdool & Mean(B) \\
\hline \multirow{5}{*}{ 悹 } & $\begin{array}{l}100 \% \text { mineral fertilization } \\
\text { (control) }\end{array}$ & 5.33 & 6.33 & 5.00 & 8.00 & 6.17 \\
\hline & $50 \%$ mineral $+50 \%$ cattle & 6.33 & 6.00 & 5.33 & 8.00 & 6.42 \\
\hline & $50 \%$ mineral $+50 \%$ chicken & 5.33 & 6.33 & 5.00 & 8.33 & 6.25 \\
\hline & $100 \%$ cattle manure & 5.33 & 5.67 & 5.00 & 6.67 & 5.67 \\
\hline & $100 \%$ chicken manure & 5.67 & 5.67 & 5.00 & 6.67 & 5.75 \\
\hline Mean & & 5.60 & 6.00 & 5.07 & 7.53 & 6.05 \\
\hline \multirow{5}{*}{$\frac{\bar{g}}{g}$} & $\begin{array}{l}100 \% \text { mineral fertilization } \\
\text { (control) }\end{array}$ & 5.33 & 6.00 & 5.67 & 7.00 & 6.00 \\
\hline & $50 \%$ mineral $+50 \%$ cattle & 5.33 & 6.00 & 5.67 & 7.00 & 6.00 \\
\hline & $50 \%$ mineral $+50 \%$ chicken & 5.33 & 6.00 & 5.67 & 7.00 & 6.00 \\
\hline & $100 \%$ cattle manure & 5.00 & 5.67 & 5.3333 & 6.67 & 5.78 \\
\hline & $100 \%$ chicken manure & 5.33 & 6.00 & 5.67 & 6.67 & 5.92 \\
\hline Mean & & 5.27 & 5.93 & 5.67 & 6.87 & 5.95 \\
\hline \multirow{5}{*}{ 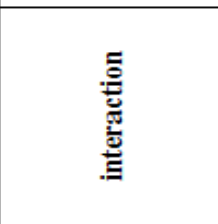 } & $\begin{array}{l}100 \% \text { mineral fertilization } \\
\text { (control) }\end{array}$ & 5.33 & 6.17 & 5.33 & 7.50 & 6.08 \\
\hline & $50 \%$ mineral $+50 \%$ cattle & 5.83 & 6.00 & 5.50 & 7.50 & 6.21 \\
\hline & $50 \%$ mineral $+50 \%$ chicken & 5.33 & 6.17 & 5.33 & 7.67 & 6.12 \\
\hline & $100 \%$ cattle manure & 5.17 & 5.67 & 5.00 & 6.67 & 5.63 \\
\hline & $100 \%$ chicken manure & 5.50 & 5.83 & 5.33 & 6.67 & 5.83 \\
\hline Mean & & 5.43 & 5.97 & 5.30 & 7.20 & \\
\hline \multicolumn{4}{|c|}{ LSD Irrigation Type } & \multicolumn{3}{|l|}{0.05} \\
\hline \multicolumn{4}{|c|}{ LSD Different Fertilization } & \multicolumn{3}{|l|}{0.07} \\
\hline \multicolumn{4}{|c|}{ LSD Different Cultivars } & \multicolumn{3}{|l|}{0.32} \\
\hline \multicolumn{4}{|c|}{ LSD Irrigation Type * Different Fertilization } & \multicolumn{3}{|l|}{0.04} \\
\hline \multicolumn{4}{|c|}{ LSD Irrigation Type Different Cultivars } & \multicolumn{3}{|l|}{0.18} \\
\hline \multicolumn{4}{|c|}{ LSD Different Fertilization * Different Cultivars } & \multicolumn{3}{|l|}{0.10} \\
\hline \multicolumn{4}{|c|}{ LSD Irrigation Type* Different Fertilization* Different Cultivars } & \multicolumn{3}{|l|}{0.04} \\
\hline
\end{tabular}




\section{REFERENCES}

Abd-El-Naim E. M., M.M., N.A. El-shintawy, Bayoumi, A. S. Farid and M.A. Negm. 1975. The influence of different sources of organic matter on calcareous soil conditions and crop yield. Agric. Research Review, Cairo, 53: 57-64.

Adel, A. A. 1980. Effect of soil conditioners on soil properties.M.Sc.Thesis, Fac. Agric., Cairo Univ.

Agboola AA, Obigbesan GO, Fayemi AAA 1975. Interrelations between organic and mineral fertilizers in the tropical rainforest of Western Nigeria. FAO Soils Bulletin No. 27: 337 - 351.

Allen, R.G., Pereira, L.S., Raes, D., Smith, M. 1998 Crop evapotranspiration guidelines for computing crop water requirements. FAO Irrigation and drainage paper 56. Food and Agriculture Organization, Rome.

Al-Subaiee, F. S., H. M. Al-Ghobari, M. B. Baig, E. A. EI- HAG and M. T. Abu-Riziga 2013. Studies on adoption of irrigation methods by the date palm farmers in al-qassim area - kingdom of Saudi Arabia. Bulgarian Journal of Agricultural Science, 19 (No 6) 2013, 1337-1345.

Amiri M. E., M. Panahi and G. Aghazadeh. 2007. Comparison of bubbler, sprinkler and basin irrigation for date palms (Phoenix dactylifera, cv. Zahdi) growth in Kish Island, Iran. Journal of Food, Agriculture \& Environment .5 : 185- 187.

Arar A 1975. Soils, irrigation and drainage of the date palm. 3rd FAO Tech. Conf. on Imp. Date Production Processing and marketing, Paper no. A. 3.

Bazza, M., 2008. Irrigated date palm production in the Near East, in: Proceedings of Workshop on "Irrigation of Date Palm and Associated Crops", in collaboration with Faculty of Agriculture, Damascus University Damascus, Syrian Arab Republic, 2007, FAO/RNE, pp: 1-15.

Black, C. A. 1969. Methods of Soil Analysis. Amer. Soc. Agron. Inc. Madison. Wisconsin. USA. 
Bokhtiar SM, Sakurai K 2005. Effects of organic manure and chemical fertilizer on soil fertility and productivity of plant and ratoon crops of sugar cane. Archives Agron. Soil Sci., 01: 325 - 334.

Bouyoucous GH 1951 A recalibration of the hydrometer for making mechanical analysis of soil. Agron. J.، 43: 434 - 438.

Bremner JM 1960. Determination of $\mathrm{N}$ in soil by the Kjeldahl method. J. Agric. Sci. 6 55: 1 -23.

Charreau C 1975. Organic matter and biochemical properties of soils of dry tropical West Africa. In: FAO (1975): Organic Materials as Fertilizers. FAO Soils Bulletin No. 27: 313 - 336.

Dayegamlye, A., R. Royer, and P. Audesse. 1997. Nitrogen mineralization and available in manure composts from Quebec biological farms. Can. J. Soil Sci., 77: 345- 350.

FAOSTAT, 2009. Crop Production 2008, Statistics Division, Food and Agriculture Organization of the United Nations.

Goyal SK. Chander M, Mundra C, Kapoor KK 1999. Influence of inorganic fertilizers and organic amendments on soil organic matter and soil microbial properties under tropical conditions. Biol. Fert. Soils 29: $196-200$.

Hati KM, Mandal KG, Misra AK, Gosh PK, Bandyopadhyay KK 2006. Effect of inorganic fertilizer and farmyard manure on soil physical properties, root distribution and water-use efficiency of soybean in Vertisols of central India. Bioresour. Technol. ، 16: $2182-2188$.

Hossain MA, Ishimine Y 2007. Effects of farmyard manure on growth and yield of turmeric (Curcuma longa L.) cultivated in dark-red soil, red soil and gray soil in Okinawa Japan. Plant Production Science 10: 146 - 150 .

Hussein, F. and M.A., Hussein. 1983. Effect of irrigation on growth, yield and fruit quality of dry dates grown at Aswan. Proc. Of the First Symp. On the Date Palm, AI-Hassa 1982, Saudi Arabia, pp. 168172. 
Jackson, M.L. 1967. Soil Chemical analysis. Prentice Hall of India, Pvt. Ltd., New Delhi: 498.

Kaur K, Kapoor KK, Gupta AP 2005. Impact of organic manures with and without mineral fertilizers on soil chemical and biological properties under tropical conditions. J. Plant Nutr. Soil Sci. ‘ 168: $1177-122$.

Kononova, M. M. 1966. Soil organic matter. Pergamon Press, Oxford, London, Edinburgh, New York

Laila, K.M. 2001. Use of Improved Organic Fertilizers as Nutrients Sources. PH. D. Thesis, Fac. Agric., Ain Shams. Univ., Egypt.

Piper, C. S. 1950. "Soils and plant analysis". Inter. Science Publisher Inc., New York.

Prasad B, Singh AP 1980. Changes in soil properties with long-term use of fertilizer, lime and farmyard manure. J. Indian Soc. Soil Sci., 28: $465-468$.

Riad, M., 1996. The date palm sector in Egypt, CIHEAM-Options Mediterraneennes, pp: 45-53.

Sarkar S, Singh SR, Singh RP 2003. The effect of organic and inorganic fertilizers on soil physical condition and the productivity of ricelentil cropping sequence in India. J. Agric. Sci.، 140 : 419 - 425.

Satyanarayana V, Vara Prasad PV, Murthy VRK, Boote KJ 2002. Influence of integrated use of farmyard manure and inorganic fertilizers on yield and yield components of irrigated lowland rice. J. Plant Nutr. 25: 2081-2090.

Sawaya, W. N., 2000. Proposal for the establishment of a regional network for date palm in the Near East and North Africa. Association of agricultural research institutions in the Near East and North Africa (AARINENA).

Tirol-Padre A, Ladha JK, Regmi A. P., Bhandari AL, Inubushi K 2007. Organic amendments affect soil parameters in two long-term rice wheat experiments. Soil Sci. Soc. Am. J.، 71: 442 - 452. 
Wahba, S.A.; Abdel Rahman, S.I.; Tayal, M.Y. and Matyn, M.A. 1990. Soil moisture, salinity, water use efficiency and sunflower growth as influenced by irrigation, bitumen mulch and plant density. Soil Technology 3, 33- 44.

Walkley A, Black I 1934. An examination of the Degtjareff method for determining soil organic matter and a proposed modification of the chromic acid titration method. Soil Sci.، 37: 29 - 38.

Westerman, R. L. 1990. Soil Testing and Plant Analysis .Third Edition.Haby, V. A., Russelle,M.P.and Skogley, E.O. Testing Soils For Potassium, Calcium, and Magnesium. Soil Sci., Soc. America, Inc. Madison, Wisconsin, USA. Pp. 181- 221

Yaduvanshi NPS 2003. Substitution of inorganic fertilizers by organic manures and the effect on soil fertility in rice-wheat rotation on reclaimed sodic soil in India. J. Agric. Sci.، (Cambridge) 140: 161-168.

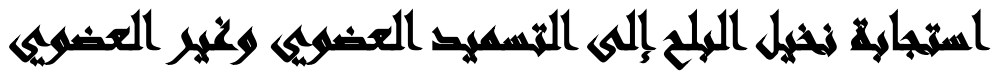

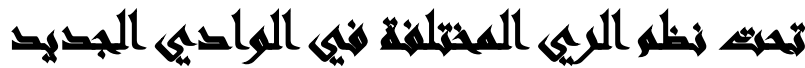

[?]

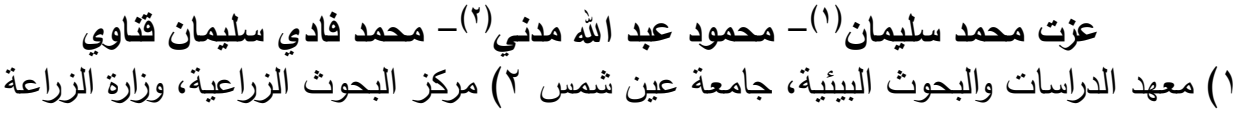

\section{المستيلم}

أجريت هذه التجربة في مركز الداخلة بمحافظة الوادي الجديد - مصر لدراسة تأثثر نظم الري الإي

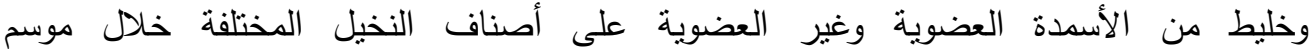

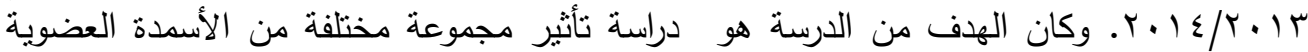

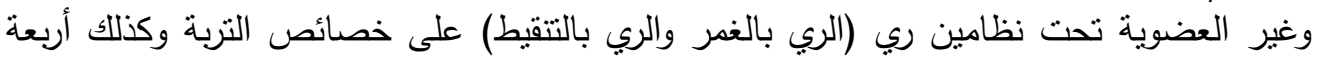

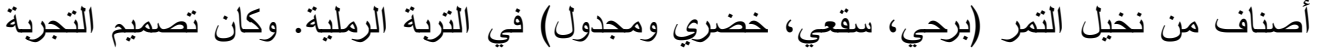

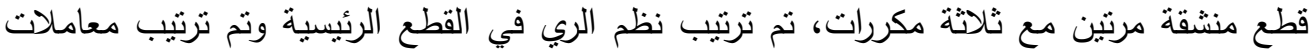

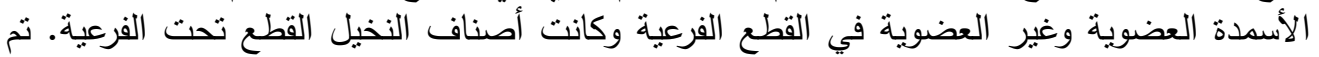


أخذ قياسات النمو الخضري (طول النخلة وعدد الأوراق) وكذلك تقدير الخواص الفيزيائية والكيميائية للتربة قبل وبعد إجراء المعاملات.

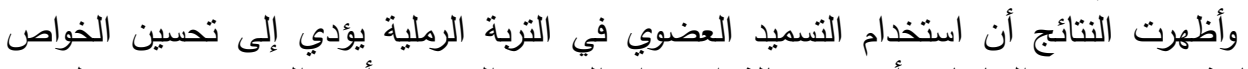

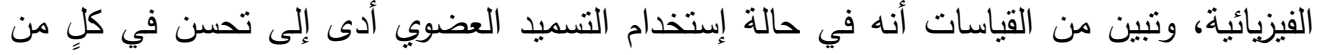

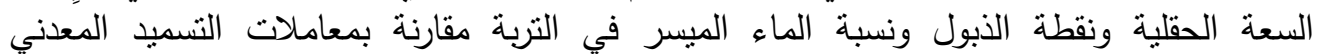

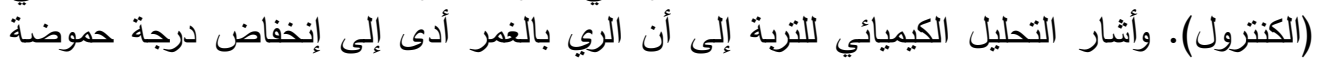

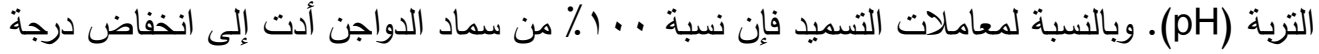

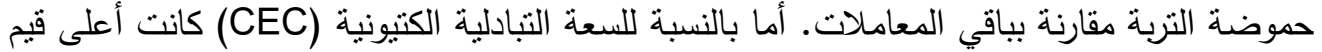

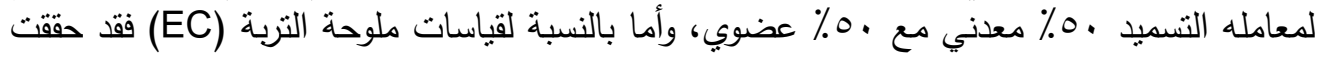

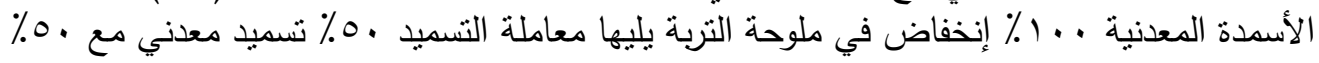
تسميد عضوي.

تأثز النمو الخضري لنخيل التمر بالتسميد العضوي تحت نظام الري بالتققيط، حيث زاد طول

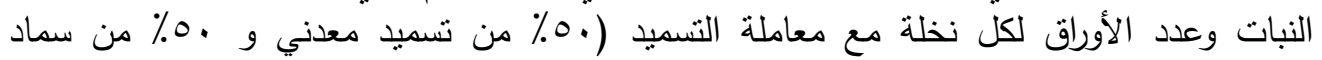
الماشية) وذلك تحت نظام الري بالتتقيط. بالنسبة لمعاملات الأصناف فقد أثنتت التجربة أنتافية أن صنف مجدول أعطى أعلى نمو مقارنة بباقي الأصناف. 